\title{
Tea Garden Lateritic Soil as a High-Temperature Desulfurization Sorbent: Effect of Oxygen on Regeneration Process
}

\author{
Tzu-Hsing Ko iD and Chen-Yao Chu 1 \\ Anxi College of Tea Science, Fujian Agricultural and Forestry University, Fuzhou, Fujian, China \\ Correspondence should be addressed to Chen-Yao Chu; serendipity1314520@gmail.com
}

Received 25 May 2018; Revised 29 June 2018; Accepted 4 July 2018; Published 19 July 2018

Academic Editor: Henryk Kozlowski

Copyright ( 2018 Tzu-Hsing Ko and Chen-Yao Chu. This is an open access article distributed under the Creative Commons Attribution License, which permits unrestricted use, distribution, and reproduction in any medium, provided the original work is properly cited.

\begin{abstract}
The lateritic soils collected from a tea garden were used to explore the regeneration process using different $\mathrm{O}_{2}$ contents for hightemperature desulfurization. The desulfurization and regeneration experiments were carried out using a fixed-bed reactor at $500^{\circ} \mathrm{C}$ and the gaseous mixture composed of $1 \% \mathrm{H}_{2} \mathrm{~S}, 25 \% \mathrm{CO}, 15 \% \mathrm{H}_{2}$, and balance $\mathrm{N}_{2}$ for the desulfurization process. Experimental results showed that the regenerability is better when the air was used as a regeneration gas and the regeneration time is shortened. Multiple regeneration experiments indicated that lateritic soils can be regenerated by passing air and can thus be reused many times and its regeneration efficiency is slightly better than that regenerated by $1 \% \mathrm{O}_{2}$. The sulfur capacity after air desulfurization/regeneration cycles was examined by elemental analysis with a value ranging from $1.40 \%$ to $1.49 \%$, and residual sulfur was detected with a value of $0.12 \%$ after the diluted $1 \% \mathrm{O}_{2}$ regeneration. No sulfur was detected for the regenerated lateritic soil after air regeneration. From NMR structural identification, the 6-coordinated octahedral structure of $\mathrm{Al}$ and trioctahedral coordinated $\mathrm{Si}$ are the major Al-containing and Si-containing compounds. Broad shoulder peaks were detected after regeneration process that may be associated with the formation of aluminosilicate and further reduces the dispersion of iron on the surface of lateritic soils.
\end{abstract}

\section{Introduction}

Hot coal gas desulfurization (HGD) is an essential procedure for advanced power generation system, such as the integrated gasification combined cycle (IGCC) and solid oxide fuel cell (SOFC) technologies. One of the crucial criteria in the development of the HGD for IGCC and SOFC is the need for a high sulfur capacity, low overall cost, high utilization, eco-friendly, and regenerable sorbent $[1,2]$. Based on the investigation of previous studies, $\mathrm{Fe}, \mathrm{Cu}, \mathrm{Zn}, \mathrm{Mn}, \mathrm{V}$, and Co oxides have been paid much attention because of their thermodynamic feasibility, reactivity, and regeneration property [3-6]. The basic desulfurization scheme is expressed by the following reaction:

$$
\mathrm{MO}_{x}+x \mathrm{H}_{2} \mathrm{~S} \longleftrightarrow \mathrm{MS}_{x}+x \mathrm{H}_{2} \mathrm{O}
$$

where MO and MS are the mean metal oxides and metal sulfides, respectively.
Regeneration is an important procedure in the HGD system. Through the regeneration reaction, the metal sulfides can be completely converted into metal oxides, and thus, the metal oxides can be used for numerous cycles. The scheme of regeneration reaction can be represented as follows:

$$
\mathrm{MS}_{x}+1.5 x \mathrm{O}_{2} \longleftrightarrow \mathrm{MO}_{x}+x \mathrm{SO}_{2}
$$

where MS and MO are the mean metal sulfides and metal oxides, respectively. Considering the overall operating cost, the regeneration process has to be operated at high temperature with diluted oxygen to avoid the exothermic reaction and further causes a deactivation of metal oxides. This shortcoming of use of diluted oxygen leads to a long-time regeneration reaction. In the past, we have investigated a series of laterites on the application of high-temperature desulfurization, and the results indicated that laterites are the potential material for high-temperature desulfurization $[7,8]$. 
To our knowledge, no research was reported on the effect of regeneration process for high-temperature desulfurization using laterites. Therefore, the regeneration process of laterites applied for high-temperature desulfurization was evaluated; some regenerating process parameters including different $\mathrm{O}_{2}$ concentrations, regenerating cycles, and the gaseous product of regenerating reaction were examined. Characterization of lateritic soil before and after regeneration process using different $\mathrm{O}_{2}$ contents was also performed with several spectroscopic techniques for the investigation of the structural change.

\section{Materials and Experimental Procedure}

The lateritic soil used in this study was collected from a tea garden in Taiwan. After sampling, unwanted materials such as leaves, plant roots, and small gravel were removed from soil samples and dried at room temperature for a week. Before use, the lateritic soils were ground with an agate mortar and sieved to pass through a $2 \mathrm{~mm}$ sieve. The contents of total iron oxides and free iron oxides were $18.45 \%$ and $4.66 \%$ determined by the inductively coupled plasma analysis after digesting with aqueous regia and dithionite citrate bicarbonate (DCB) procedure [9]. The basic physicochemical properties of the lateritic soil are shown in Table 1.

The experiment was carried out in a bench-scale fixedbed reactor at $500^{\circ} \mathrm{C}$. The reactor consisted of a quartz tube, $1.6 \mathrm{~cm}$ i.d., $2.0 \mathrm{~cm}$ o.d., and $150 \mathrm{~cm}$ long, located inside an electric furnace. The quartz fibers were set in the reactor to support the lateritic soils. The gaseous mixture composed of $1 \% \mathrm{H}_{2} \mathrm{~S}, 25 \% \mathrm{CO}, 15 \% \mathrm{H}_{2}$, and a balance of $\mathrm{N}_{2}$ from regulation cylinders. The air and diluted $\mathrm{O}_{2}$ used in the regeneration process were supplied from the regulation cylinder. The diluted $\mathrm{O}_{2}$ was prepared with $1 \% \mathrm{O}_{2}$ and a balance of $\mathrm{N}_{2}$ (99.9\% purity, San Fu). Two K-type thermocouples were inserted into the reactor to the positions at the top and bottom of the soil samples to enable the inlet and outlet temperatures to be accurately measured and controlled. Three grams of the lateritic soils was packed in the reactor for each run. The gas flow was controlled at a rate of $100 \mathrm{~mL} \cdot \mathrm{min}^{-1}$. The inlet and outlet concentrations of $\mathrm{H}_{2} \mathrm{~S}$ were analyzed by an online gas chromatograph (HP, GC5890) equipped with a flame photometry detector (FPD). The breakthrough time was defined as the time from the beginning of the reaction to the point when the outlet concentration of $\mathrm{H}_{2} \mathrm{~S}$ reached $100 \mathrm{ppm}$. Following $\mathrm{H}_{2} \mathrm{~S}$ removal reaction, the reactor was purged with nitrogen gas for $15 \mathrm{~min}$, and then the air and diluted $\mathrm{O}_{2}(1 \%)$ were used for regeneration run. The regeneration experiment was terminated when the concentration of $\mathrm{SO}_{2}$ in the effluent gas was below $50 \mathrm{ppm}$.

X-ray photoelectron spectroscopy (XPS) was performed using a Kratos Axis Ultra spectrometer with a $\mathrm{Mg} \mathrm{K} \alpha$ X-ray radiation source $(1253.6 \mathrm{eV})$. The plate was then placed in a pretreatment chamber attached to the instrument. The chamber pressure was then decreased from 100 to $1.33 \times 10^{-10} \mathrm{kPa}$ via a turbo pump. The time needed to reach the final pressure was approximately $4 \mathrm{hrs}$. A gate valve between the pretreatment chamber and a vacuum chamber was then opened after the pretreatment. The sample was moved to the vacuum chamber for analysis. The pressure in the vacuum chamber was maintained at $1.33 \times 10^{-10} \mathrm{kPa}$ via an ion pump. The data analysis procedure generally involved background subtraction by a Shirley-type integral profile and a curve-fitting procedure by the least-squares method.

Elementar vario EL III Heraeus CHNOS Rapid F002, equipped with a flash combustion furnace and thermal conductivity detector (TCD), was used to measure the sulfur content of the lateritic soil before and after desulfurization and regeneration process.

Lateritic soil samples were examined with a Rigaku Model D/MAX III-V X-ray powder diffractometer (XRD) equipped with a $\mathrm{Ni}$-filtered $\mathrm{Cu} \mathrm{K} \alpha$ radiation generated at $30 \mathrm{~mA}$ and $40 \mathrm{kV}$. The diffraction patterns were recorded from $10^{\circ}$ to $80^{\circ}$ with a scan rate of $3^{\circ} \mathrm{min}^{-1}$. The solid-state ${ }^{27} \mathrm{Al}$ MAS (magic angle spinning) NMR and ${ }^{29}$ Si MAS NMR spectra of the lateritic soil samples were recorded under 9.4 Tesla with operating frequencies of 79.4 and $104.2 \mathrm{MHz}$, respectively, on a Bruker Avance DSX400 spectrometer. Zirconia rotors were spun in air at $5 \mathrm{kHz}$.

\section{Results and Discussions}

First of all, it is very important to explore the effect of other metals on the desulfurization. It is reported that the Fe, Mn, $\mathrm{Cu}, \mathrm{Zn}$, and Co have the favorable thermodynamic property for high-temperature desulfurization [3-6]. In the past, we have investigated a great number of soil samples for hightemperature desulfurization, and some important information was proposed $[10,11]$. The contents of $\mathrm{Cu}, \mathrm{Zn}$, and $\mathrm{Co}$ in the normal soil are relatively lower, and their contribution to desulfurization is lesser although they have excellent reactivity with $\mathrm{H}_{2} \mathrm{~S}$. As shown in Table 1 , the contents of $\mathrm{Cu}, \mathrm{Zn}, \mathrm{Mn}$, and Co are relatively lower in comparison with $\mathrm{Al}, \mathrm{Si}$, and Fe. Therefore, the effect of $\mathrm{Cu}$, $\mathrm{Zn}, \mathrm{Mn}$, and Co on desulfurization in this study could be ignored. On the other hand, it is well known that $\mathrm{Al}_{2} \mathrm{O}_{3}$ and $\mathrm{SiO}_{2}$ are widely used as carrier (or supports) to prepare the supported catalyst in chemical engineering application because of good dispersion, porosity structure, and heat resistance. Lateritic soil contains large amounts of $\mathrm{Al}$ and $\mathrm{Si}$, and due to the long-term weathering in nature, the distribution of $\mathrm{Al}$ and $\mathrm{Si}$ can be regarded as a homogeneous state and plays the carrier role to support Fe dispersed on the surface of lateritic soil. Our previous research showed that the desulfurization efficiency was less than $1 \%$ for lateritic soils after extracting Fe. This indicated that the major desulfurization reaction is attributed to the reaction of $\mathrm{H}_{2} \mathrm{~S}$ and Fe. The effect of $\mathrm{Al}$ and $\mathrm{Si}$ on desulfurization and regeneration could also be ignored $[10,11]$.

In the regenerating process, the product $\mathrm{SO}_{2}$ is the major component to determine the extent of regeneration for sulfided sorbent. The formation of $\mathrm{SO}_{2}$ is expressed as follows:

$$
2 \mathrm{FeS}+3.5 \mathrm{O}_{2} \longrightarrow \mathrm{Fe}_{2} \mathrm{O}_{3}+2 \mathrm{SO}_{2}
$$

To understand the $\mathrm{SO}_{2}$ evolution during the regeneration process, the sulfided lateritic soil was regenerated 
TABLE 1: The basic physicochemical properties of the tea garden lateritic soil used in this study.

\begin{tabular}{|c|c|c|c|c|c|c|c|c|c|c|c|}
\hline $\begin{array}{l}\mathrm{pH} \\
\left(\mathrm{H}_{2} \mathrm{O}\right) \\
\end{array}$ & Texture & $\begin{array}{c}\mathrm{Cu}^{*} \\
(\mathrm{ppm})\end{array}$ & $\begin{array}{c}\mathrm{Zn}^{*} \\
(\mathrm{ppm})\end{array}$ & $\begin{array}{l}\mathrm{Mn}^{*} \\
(\mathrm{ppm})\end{array}$ & $\begin{array}{c}\mathrm{Co}^{*} \\
(\mathrm{ppm})\end{array}$ & $\mathrm{Al}^{*}(\%)$ & $\mathrm{Si}^{*}(\%)$ & $\mathrm{Fe}^{*}(\%)$ & 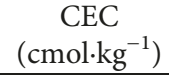 & $\begin{array}{c}\mathrm{CBD}-\mathrm{Fe} \\
\left(\mathrm{Fe}_{2} \mathrm{O}_{3}\right)(\%)\end{array}$ & $\begin{array}{l}\text { CBD-Mn } \\
\left(\mathrm{mg} \cdot \mathrm{kg}^{-1}\right)\end{array}$ \\
\hline 4.2 & Loam & $64 \pm 3$ & $1621 \pm 58$ & $677 \pm 42$ & $26.2 \pm 1.4$ & $15.84 \pm 1.05$ & $21.52 \pm 1.57$ & $12.92 \pm 1.14$ & $7.8 \pm 0.36$ & $4.66 \pm 0.22$ & $225 \pm 7$ \\
\hline
\end{tabular}

${ }^{*}$ The values were determined by ICP analysis after an aqua digestion at $120^{\circ} \mathrm{C}$ for $8 \mathrm{~h}$.

with air and diluted $\mathrm{O}_{2}$, and the outlet concentration of $\mathrm{SO}_{2}$ was systematically recorded for the multiple regenerating cycles. As shown in Figure 1, the regeneration time ranged between 80 and 100 min when the diluted $\mathrm{O}_{2}$ was used as a regenerating gas, whereas a very rapid regenerating time can be found when the air was used. This is due to the fact that the air contains more $\mathrm{O}_{2}$ to increase the regeneration reaction and to shorten the regenerating time. On the other hand, the maximum $\mathrm{SO}_{2}$ concentrations for diluted $\mathrm{O}_{2}$ and air were $5612 \mathrm{ppm}$ and 121,032 ppm, respectively. Based on the thermodynamic calculation of the reaction between $\mathrm{FeS}$ and $\mathrm{O}_{2}$, the $\mathrm{SO}_{2}$ equilibrium concentrations are 5,710 and $118,800 \mathrm{ppm}$ when the diluted $\mathrm{O}_{2}\left(1 \% \mathrm{O}_{2}\right)$ and air were used as regeneration gases. This result revealed that air can be used as a regeneration gas to replace diluted $\mathrm{O}_{2}$, and the regeneration reaction obeys (3).

Figure 2 shows the five consecutive regeneration cycles using diluted $\mathrm{O}_{2}(1 \%)$ and air as regeneration gases. Note that the breakthrough time after air regeneration was slightly higher than that of the diluted $\mathrm{O}_{2}$. The average breakthrough time for air regeneration ranged from $27.3 \mathrm{~min}$ to $29.9 \mathrm{~min}$, whereas that for diluted $\mathrm{O}_{2}$ regeneration ranged from $30.3 \mathrm{~min}$ to $32.4 \mathrm{~min}$. For better understanding of the actual sulfur capacity in the lateritic soil after desulfurization reaction, the reacted lateritic soils were measured by the elemental analyzer (EA) for sulfur determination. The breakthrough time shown in Figure 2(a) for multiple air regeneration cycles is $32.4 \mathrm{~min}$, $31.7 \mathrm{~min}, 30.3 \mathrm{~min}, 31.2 \mathrm{~min}$, and $30.6 \mathrm{~min}$ in which sulfur capacity measured by EA is $1.49 \%, 1.46 \%, 1.40 \%, 1.44 \%$, and $1.41 \%$, respectively. For the diluted $\mathrm{O}_{2}(1 \%)$ regeneration cycles, the sulfur capacity is $1.34 \%, 1.31 \%, 1.33 \%, 1.27 \%$, and $1.26 \%$ which corresponds to the breakthrough time results. EA analysis demonstrated that the regeneration by air is better than that by diluted $\mathrm{O}_{2}$ because of the higher sulfur content for air regeneration. For both cases, the breakthrough time appeared to have a slight decrease after the first regeneration process. No severe deactivation was observed after five consecutive regeneration cycles for different $\mathrm{O}_{2}$ contents.

To understand the change in temperature during the regeneration process, the changes in temperature during the regeneration process using different $\mathrm{O}_{2}$ contents were recorded. In the case of air, the temperature increased rapidly from $500^{\circ} \mathrm{C}$ to $750^{\circ} \mathrm{C}$ and remained around $2 \mathrm{~min}$ and then gradually decreased. For diluted $\mathrm{O}_{2}$, the temperature rapidly increased from $500^{\circ} \mathrm{C}$ to $650^{\circ} \mathrm{C}$ and the temperature of $650^{\circ} \mathrm{C}$ maintained around $40 \mathrm{~min}$, indicating that the operation with diluted $\mathrm{O}_{2}$ has a lower regenerability compared to the air. The increase in temperature for both cases is attributed to the exothermic reaction. It is believed that the exothermic reaction will cause the increase in temperature and thus is beneficial to the regeneration reaction. Although higher temperature is favorable for the regeneration reaction, it may cause a sintering effect and results in the deactivation of the lateritic soil after multiple regeneration cycles. A series of analyses in lateritic soil after different treatments are tabulated in Table 2. Note that no huge changes in surface area were observed. Approximately $15 \%$ and $20 \%$ BET surface area were lost after five consecutive cycles for diluted $\mathrm{O}_{2}$ and air. This implies that the pore structure did not suffer from a severe damage, and the extent of sintering has little effect to the lateritic soil after multiple regeneration cycles. From the XPS analysis, the binding energy for all soil samples was around $711 \mathrm{eV}$, and the major iron species present in lateritic soil is in the form of $\mathrm{Fe}^{3+}$ and is assigned to hematite $\left(\alpha-\mathrm{Fe}_{2} \mathrm{O}_{3}\right)$. This result coincides with the observation of XRD, in which a small but detectable peak was measured at $2 \theta=33.21$. This finding strongly implies that the hematite is the major iron species present in the lateritic soil. Furthermore, as shown in Figure 3, a higher binding energy of $S_{2 p}$ was observed in the case of $1 \% \mathrm{O}_{2}$ regeneration. In general, two ranges of $S_{2 p}$ were commonly observed, namely, around $161-164 \mathrm{eV}$ and $167-170 \mathrm{eV}$. The range of $161-164 \mathrm{eV}$ is assigned to sulfide and elemental sulfur, whereas the range $167-170 \mathrm{eV}$ is assigned to sulfite and sulfate [12-14]. Based on this information, it is suggested that the XPS spectrum of $S_{2 p}$ centered on $168.6 \mathrm{eV}$ is assigned to sulfate. The formation of sulfate is attributed to the reaction between $\mathrm{O}_{2}$ and $\mathrm{FeS}$ during the regeneration process. In the case of air, it is believed that the sulfate can be formed because of the thermodynamically favorable reaction between $\mathrm{O}_{2}$ and metal sulfide. However, the maximum temperature of $750^{\circ} \mathrm{C}$ was found when the air was used as a regenerating gas. Under such high temperature, the sulfate is decomposed to $\mathrm{SO}_{2}$ and metal oxides, and no sulfur species is detected through XPS analysis. From EA analysis, a trace amount of sulfur was detected with a value of $0.12 \%$ after the diluted $\mathrm{O}_{2}(1 \%)$ regeneration. No sulfur was detected for the regenerated lateritic soil after air regeneration.

Additionally, ${ }^{27} \mathrm{Al}$ MAS NMR and ${ }^{29}$ Si MAS NMR were also measured and are recorded in Table 1 . The chemical shift of ${ }^{27} \mathrm{Al}$ for all soil samples detected at $-0.6 \mathrm{ppm}$ and $69 \mathrm{ppm}$ was assigned to a 6 -coordinated octahedral structure $\left(\mathrm{Al}^{6}\right)$ and 4-coordinated tetrahedral structure $\left(\mathrm{Al}^{4}\right) . \mathrm{Al}^{4}$ denotes the structure of aluminum with 3 nearest neighbor $\mathrm{Si}$ atoms. For all soil samples, the octahedral phase is the main structure, followed by the tetrahedral phase. With a regression fitting analysis, the proportion of $\mathrm{Al}^{6}$ is $82.4 \%$, $75.8 \%$, and $78.3 \%$ for fresh and both regenerated soil samples. The proportion of $\mathrm{Al}^{4}$ significantly increased and that of $\mathrm{Al}^{6}$ decreased after the regeneration reaction. The reasonable explanation of this finding is likely ascribed to the fact that coordination of aluminum underwent significant 


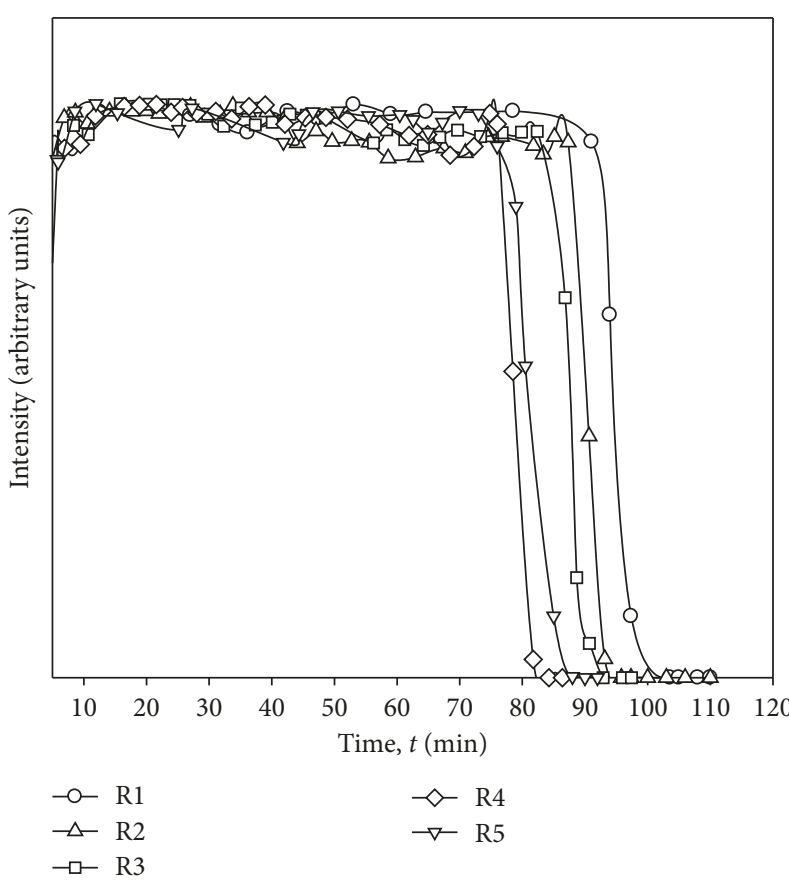

(a)

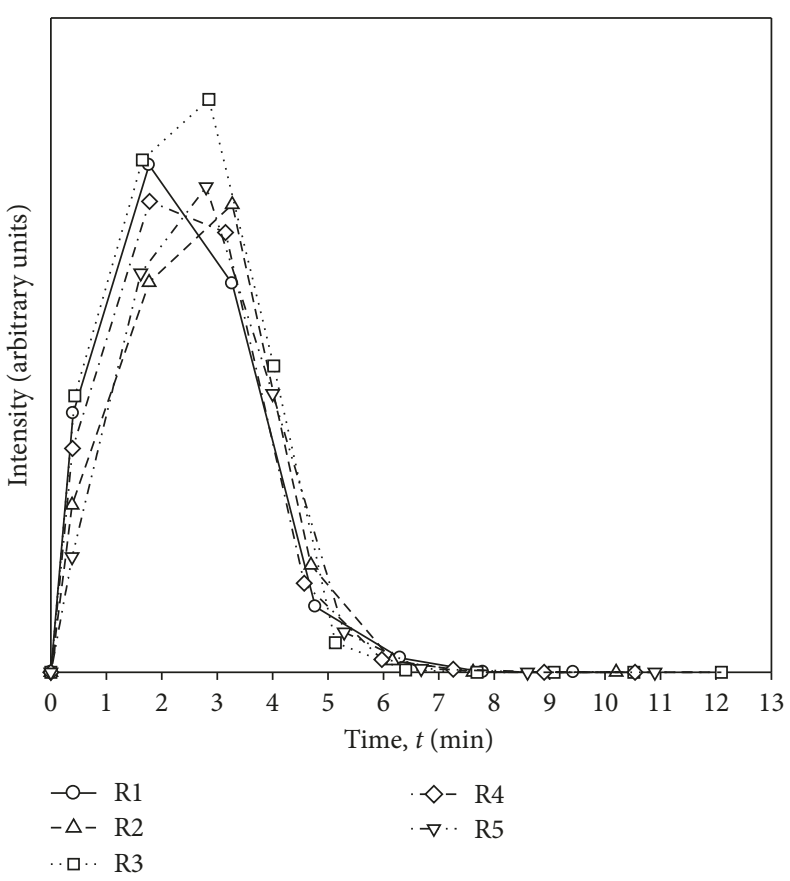

(b)

Figure 1: Evolution of $\mathrm{SO}_{2}$ as a function of time using (a) diluted $1 \% \mathrm{O}_{2}$ and (b) air at $500^{\circ} \mathrm{C}$.

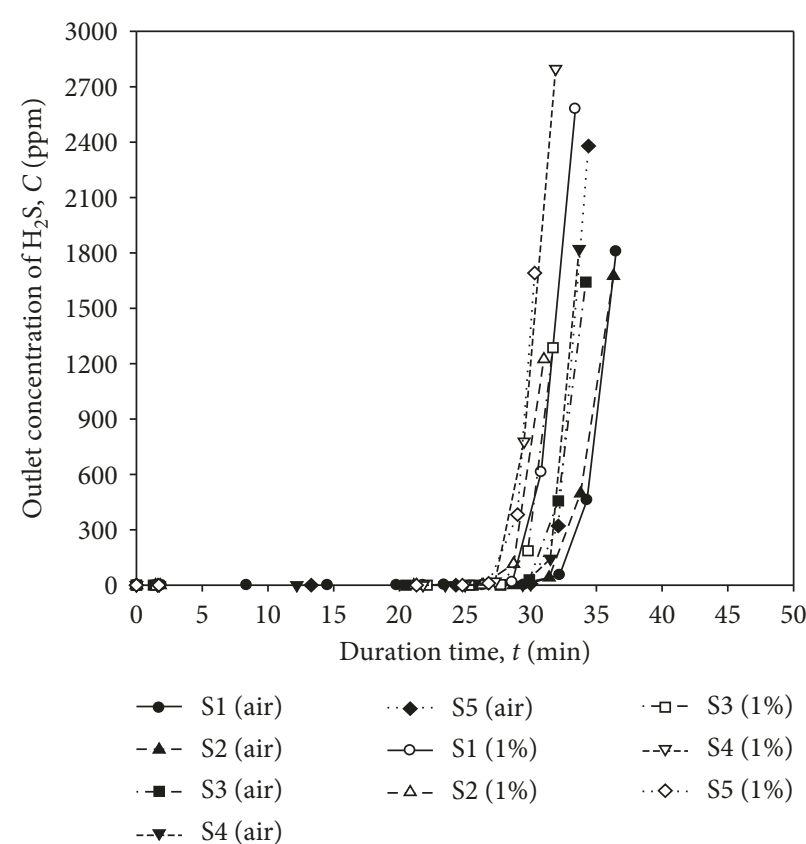

(a)

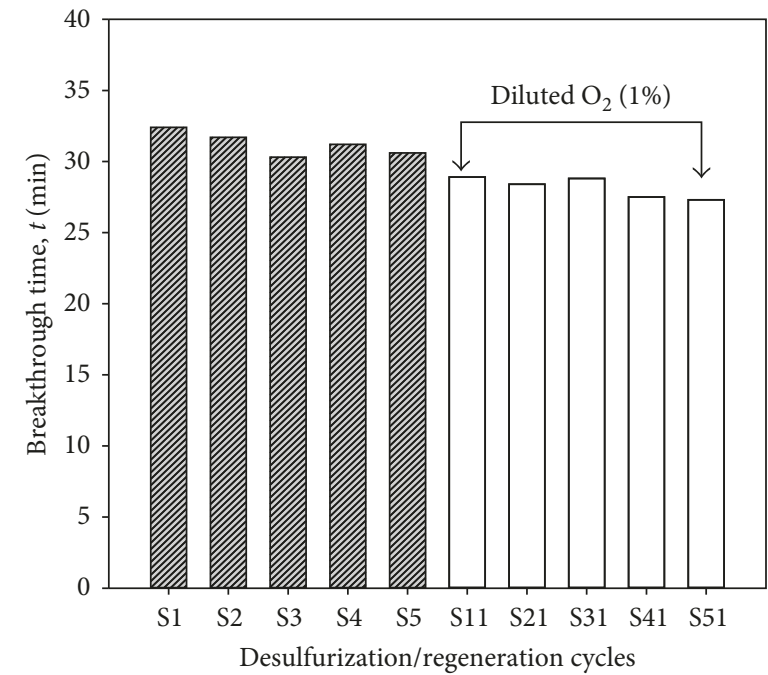

(b)

FIgure 2: (a) Multiple regeneration cycles and (b) breakthrough time profile for different oxygen regeneration treatments.

changes resulting from the dehydroxylation or the formation of aluminosilicate under strong exothermic reaction from the regeneration process $[15,16]$. For ${ }^{29} \mathrm{Si}$ NMR, a sharp peak located around $-90 \mathrm{ppm}$ was detected, which implies the presence of $Q^{3}(0 \mathrm{Al})$ linked to three $\mathrm{Si}$ atoms via bridging oxygen atoms and is characteristic of layered silicates. No obvious signals centered between $-103 \mathrm{ppm}$ and $-110 \mathrm{ppm}$ were detected for fresh lateritic soil. The resonances between these ranges are associated with the $Q^{4}$ $(0 \mathrm{Al})$ site corresponding to the presence of crystalline $\mathrm{Si}$ and Si-O-Si trioctahedral structure [17]. As shown in Figure 3, the resonance around $-62 \mathrm{ppm}$ was not detected for both 
TABLE 2: Spectroscopic and surface area analyses of the lateritic soil under different regenerating operations.

\begin{tabular}{lccc}
\hline & Fresh soil & $\begin{array}{c}\text { Air } \\
\text { regeneration }\end{array}$ & $\begin{array}{c}1 \% \mathrm{O}_{2} \\
\text { regeneration }\end{array}$ \\
\hline $\begin{array}{l}\text { BET surface } \\
\text { area }\end{array}$ & $31.4 \mathrm{~m}^{2} \mathrm{~g}^{-1}$ & $25.5 \mathrm{~m}^{2} \mathrm{~g}^{-1}$ & $26.3 \mathrm{~m}^{2} \mathrm{~g}^{-1}$ \\
\hline${ }^{29} \mathrm{Si} \mathrm{NMR}$ & $\mathrm{Q}^{4}: 0 \%$ & $\mathrm{Q}^{4}: 18.3 \%$ & $\mathrm{Q}^{4}: 14.6 \%$ \\
$Q^{3}: 87.6 \%$ & $Q^{3}: 81.7 \%$ & $\mathrm{Q}^{3}: 85.4 \%$ \\
\hline${ }^{27} \mathrm{Al} \mathrm{NMR}$ & $\mathrm{Al}^{6}: 82.4 \%$ & $\mathrm{Al}^{6}: 75.8 \%$ & $\mathrm{Al}^{6}: 78.3 \%$ \\
$\mathrm{Al}^{4}: 17.6 \%$ & $\mathrm{Al}^{4}: 24.2 \%$ & $\mathrm{Al}^{4}: 21.7 \%$ \\
\hline \multirow{2}{*}{$\mathrm{XRD}$} & $\mathrm{SiO}_{2}$ & $\mathrm{SiO}_{2}$ & $\begin{array}{c}\mathrm{SiO}_{2} \\
\end{array}$ \\
\hline \multirow{2}{*}{ XPS } & $(2 \theta=33.2)$ & $(2 \theta=33.2)$ & $\begin{array}{c}\alpha-\mathrm{Fe}_{2} \mathrm{O}_{3} \\
(2 \theta=33.2)\end{array}$ \\
\hline
\end{tabular}

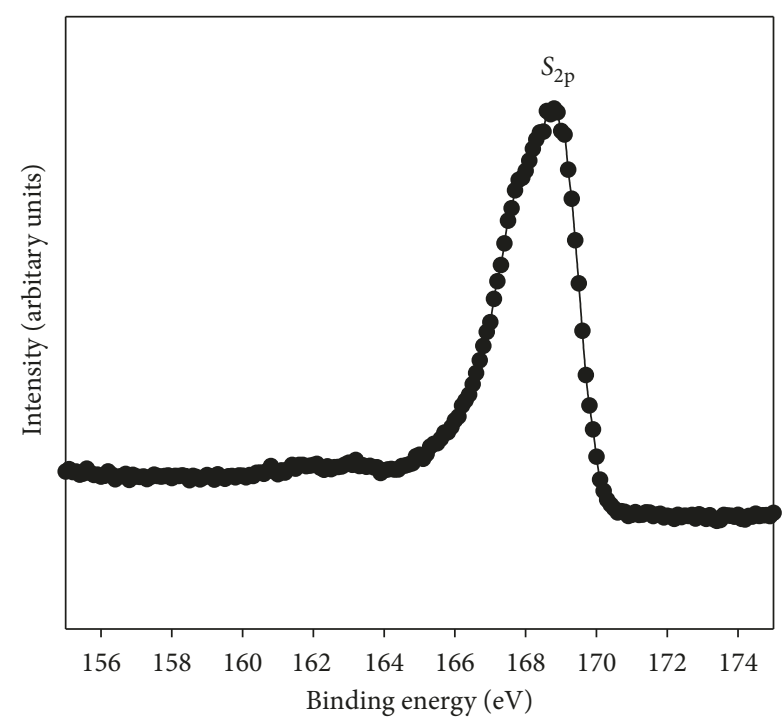

FIGURE 3: XPS spectrum analysis of $S_{2 p}$ for the regenerated lateritic soil after diluted $1 \% \mathrm{O}_{2}$ regeneration.

soil samples, which indicated that no side reaction had taken place between $\mathrm{Si}$ and $\mathrm{C}$ to form a structure of Si-C linkage [18]. After regeneration process, a resolved signal located around $-105 \mathrm{ppm}$ was detected and can be assigned to $Q^{4}$. Moreover, broad shoulder peaks located between $-80 \mathrm{ppm}$ and $-85 \mathrm{ppm}$ were detected for the regenerated soil. The appearance between these ranges is likely attributed to the $Q^{3}(1 \mathrm{Al}), Q^{3}(2 \mathrm{Al})$, and $Q^{3}(3 \mathrm{Al})$, which demonstrates that the $\mathrm{Si}$ atoms are surrounded by $\mathrm{Al}$ atoms $[19,20]$. The formation of $Q^{3}$ structure linkage with $\mathrm{Al}$ atoms may be attributed to a portion of $\mathrm{Al}$ released in the free state and reacted with $\mathrm{Si}$ to form aluminosilicate minerals, which reflects on the existence of $Q^{3}(1 \mathrm{Al}, 2 \mathrm{Al}$, and $3 \mathrm{Al})$ detected in the ${ }^{27} \mathrm{Si}$ NMR spectra [21] (Figure 4).

\section{Conclusions}

It is concluded from this study that the air has a better regenerability than that of diluted $\mathrm{O}_{2}$ in the regeneration process for high-temperature desulfurization. Spectroscopic

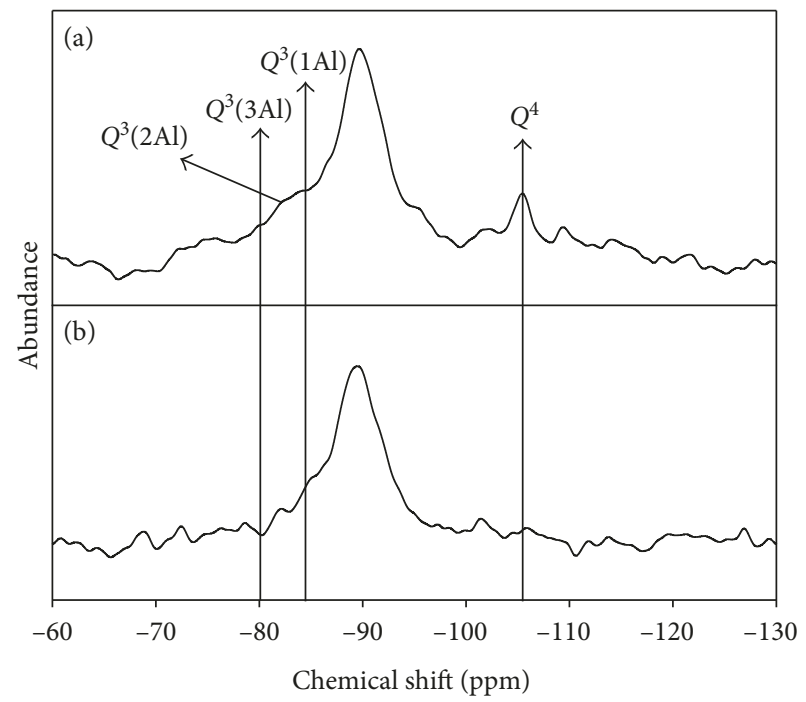

FIgURE 4: ${ }^{29} \mathrm{Si}$ NMR spectra of (a) regenerated soil sample treated by air and (b) fresh soil.

investigation revealed that there were no destructive changes in the structure of the lateritic soil after the regeneration process. From XPS and XRD analysis, it is found that the hematite $\left(\alpha-\mathrm{Fe}_{2} \mathrm{O}_{3}\right)$ is the main iron species after the regeneration process. The bonding and distribution between $\mathrm{Si}$ and $\mathrm{Al}$ were found to be different after the treatment of two regeneration gases. The $Q^{4}$ distribution increased whereas $Q^{3}$ distribution decreased after the regeneration process. The formation of $Q^{3}$ structure linkage with $\mathrm{Al}$ atoms may be attributed to a portion of $\mathrm{Al}$ is released in the free state and reacted with $\mathrm{Si}$ to form aluminosilicate minerals.

\section{Data Availability}

The data used to support the findings of this study are available from the corresponding author upon request.

\section{Conflicts of Interest}

The authors declare that there are no conflicts of interest regarding the publication of this paper.

\section{Authors' Contributions}

All authors have contributed to the intellectual content of this paper. Tzu-Hsing Ko conceived and designed the experiments and supervised the data analysis. Chen-Yao Chu carried out the experiments and analysis of the experimental results. Chen-Yao Chu wrote the paper and Tzu-Hsing Ko provided many suggestions and revised this paper. All authors have read and approved the final manuscript.

\section{Acknowledgments}

This work was partially funded by Anxi College of Tea Science, Fujian Agriculture and Forestry University, with a Grant no. AXCXY-114-11001014. The authors appreciate 
Yung-Hsing Financial Workshop Cooperation Company for XPS and XRD measurements.

\section{References}

[1] M. Chomiak and J. Trawczynski, "Effect of titania on the properties of $\mathrm{Zn}-\mathrm{Fe}-\mathrm{O}$ sorbents of hydrogen sulfide," Fuel Processing Technology, vol. 134, pp. 92-97, 2005.

[2] Z. F. Zhang, B. S. Liu, F. Wang, and J. F. Li, "Fabrication and performance of xMnyCe/hexagonal mesoporous silica sorbents with wormhole-like framework for hot coal gas desulfurization," Energy Fuels, vol. 27, no. 12, pp. 7754-7761, 2013.

[3] D. Liu, S. Chen, X. Fei, C. Huang, and Y. Zhang, "Regenerable CuO-based adsorbents for low temperature desulfurization application," Industrial and Engineering Chemistry Research, vol. 54, no. 14, pp. 3556-3562, 2015.

[4] T. H. Ko, S. Wang, F. H. Chang, and C. Y. Chu, "Performance of $\mathrm{ZnMn}_{2} \mathrm{O}_{4} / \mathrm{SiO}_{2}$ sorbent for high temperature $\mathrm{H}_{2} \mathrm{~S}$ removal from hot coal gas," RSC Advances, vol. 7, no. 57, pp. 35795-35804, 2017.

[5] P. R. Westmoreland and D. P. Harrison, "Evaluation of candidate solids for high-temperature desulfurization of lowBtu gases," Environmental Science and Technology, vol. 10, no. 7, pp. 659-661, 1976.

[6] T. Baird, K. C. Campbell, P. J. Holliman et al., "Cobalt-zinc oxide absorbents for low temperature gas desulfurisation," Journal of Materials Chemistry, vol. 9, no. 2, pp. 599-605, 1999.

[7] T. H. Ko, "Removal of hydrogen sulfur from coal-derived gas by iron oxides in various oxisols," Environmental Engineering Science, vol. 25, no. 7, pp. 969-973, 2008.

[8] T. H. Ko and H. T. Hsueh, "Removal of hydrogen sulfide by iron-rich soil: application of the deactivation kinetic model for fitting breakthrough curve," Aerosol and Air Quality Research, vol. 12, pp. 1355-1361, 2012.

[9] O. P. Mehra and M. L. Jackson, "Iron oxide removal from soils and clays by a dithionite-citrate system buffered with sodium bicarbonate," Clays and Clay Minerals, vol. 7, no. 1, pp. 317-327, 1960.

[10] T. H. Ko and H. Chu, "Feasibility study on high-temperature sorption of hydrogen sulfide by natural soils," Chemosphere, vol. 64, no. 6, pp. 881-891, 2006.

[11] T. H. Ko, "Application of Zn-contaminated soil: feasibility study on the removal of $\mathrm{H}_{2} \mathrm{~S}$ from hot coal-derived gas," Environmental Chemistry Letters, vol. 9, no. 1, pp. 77-82, 2011.

[12] K. Laajalehto, I. Kartio, and P. Nowak, "XPS study of clean metal sulfide surfaces," Applied Surface Science, vol. 81, no. 1, pp. 11-15, 1994.

[13] M. I. De Barros, J. Bouchet, I. Raoult et al., "Friction reduction by metal sulfides in boundary lubrication studied by XPS and XANES analyses," Wear, vol. 254, no. 9, pp. 863-870, 2003.

[14] L. V. Duong, B. J. Wood, and J. T. Kloprogge, "XPS study of basic aluminum sulphate and basic aluminium nitrate," Material Letters, vol. 59, no. 14-15, pp. 1932-1936, 2005.

[15] H. P. He, J. G. Guo, J. X. Zhu, and C. Hu, " ${ }^{29}$ Si and ${ }^{27} \mathrm{Al} \mathrm{MAS}$ NMR study of the thermal transformations of kaolinite from North China," Clay Minerals, vol. 38, no. 4, pp. 551-559, 2003.

[16] P. Dion, J. F. Alcover, F. Bergaya, A. Ortega, P. L. Llewellyn, and F. Rouquerol, "Kinetic study by controlled-transformation rate thermal analysis of the dehydroxylation of kaolinite," Clay Minerals, vol. 33, no. 2, pp. 269-276, 1998.
[17] J. G. Jang and H. K. Lee, "Effect of fly ash characteristics on delayed high-strength development of geopolymers," Construction and Building Materials, vol. 102, pp. 260-269, 2016.

[18] S. J. Widgeon, S. Sen, G. Mera, E. Ionescu, R. Riedel, and A. Navrotsky, ${ }^{29} \mathrm{Si}$ and ${ }^{13} \mathrm{C}$ solid-state NMR spectroscopic study of nanometer-scale structure and mass fractal characteristics of amorphous polymer derived silicon oxycarbide ceramics," Chemistry of Materials, vol. 22, no. 23, pp. 62216228, 2010.

[19] C. A. Weiss, S. P. Altaner, and R. J. Kirkpartrick, "Highresolution ${ }^{29} \mathrm{Si}$ NMR spectroscopy of 2:1 layer silicates; correlations among chemical shift, structural distortions, and chemical variations," American Mineralogist, vol. 72, no. 1, pp. 935-942, 1987.

[20] M. Mantovani, A. Escudero, and A. I. Becerro, "Application of ${ }^{29} \mathrm{Si}$ and ${ }^{27} \mathrm{Al}$ MAS NMR spectroscopy to the study of the reaction mechanism of kaolinite to illite/muscovite," Clay and Clay Minerals, vol. 57, pp. 302-310, 2009.

[21] T. H. Ko, High temperature sorption of hydrogen sulfide from coal derived gas, Ph.D. dissertation, National Cheng Kung University, Tainan City, Taiwan, 2005. 

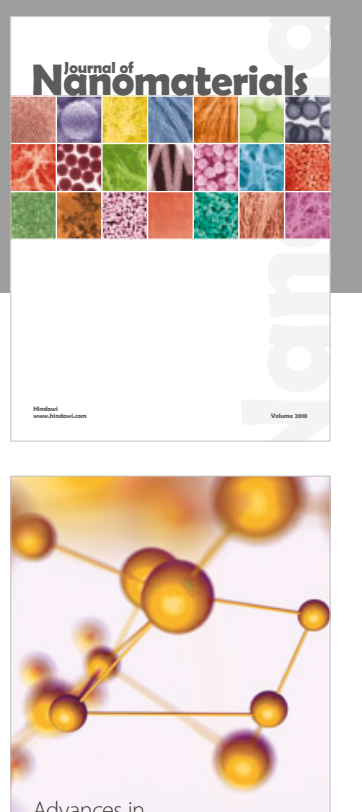

Physical Chemistry
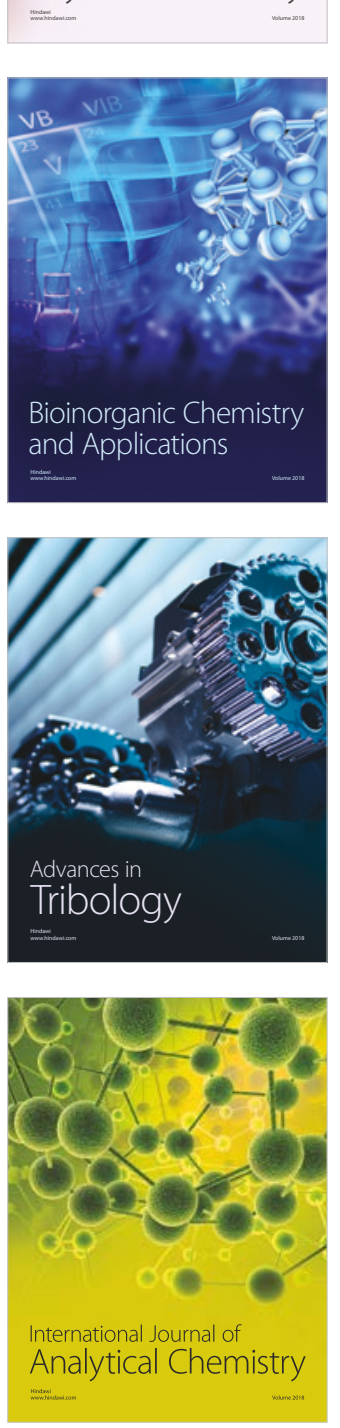

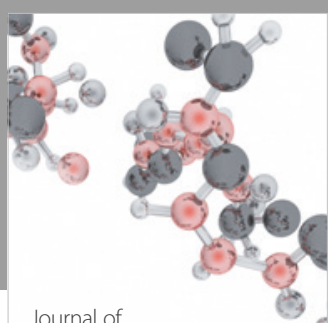

Analytical Methods

in Chemistry

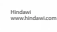

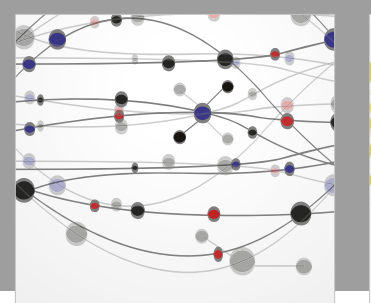

The Scientific World Journal

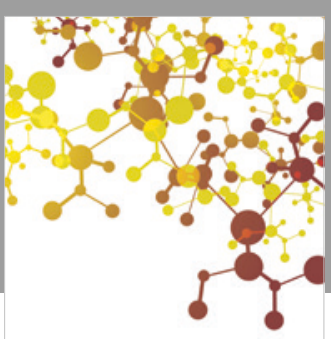

Journal of

Applied Chemistry
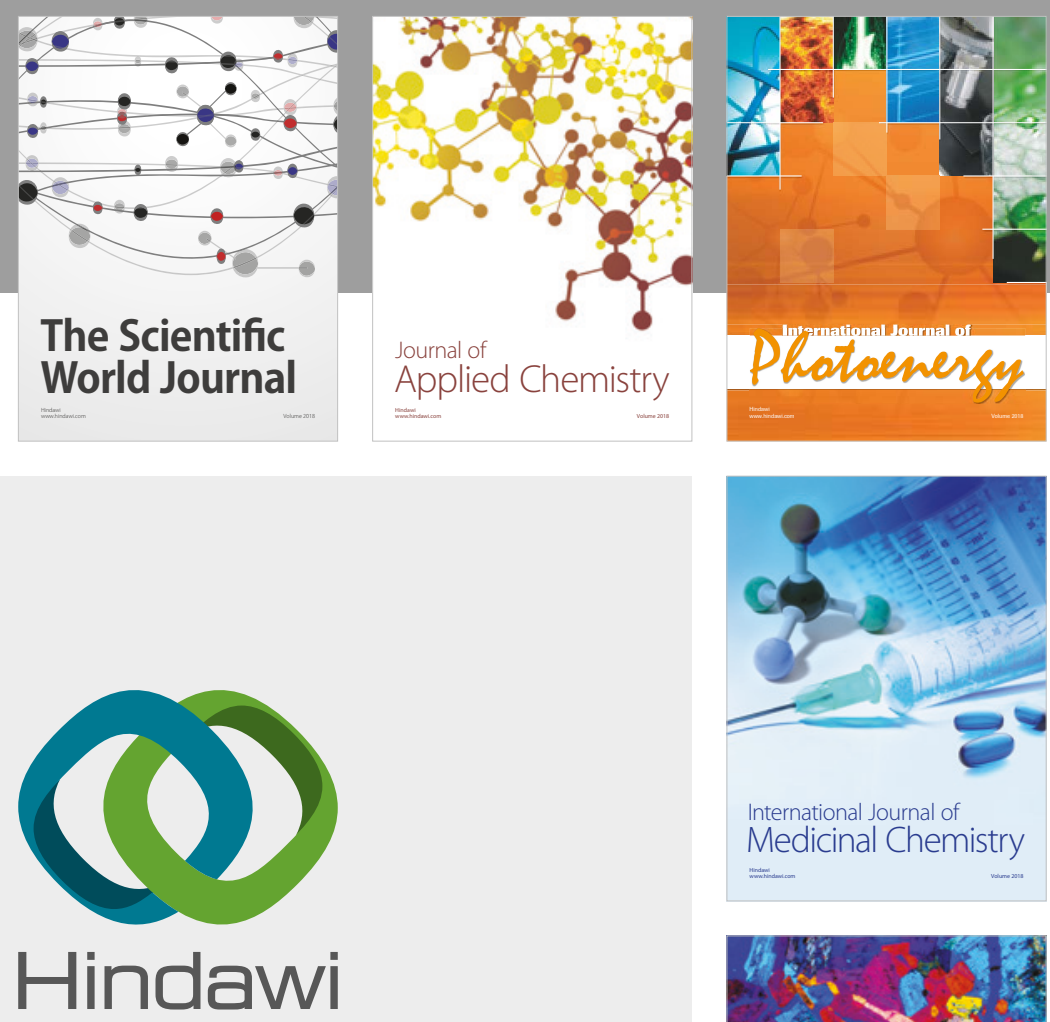

Submit your manuscripts at

www.hindawi.com
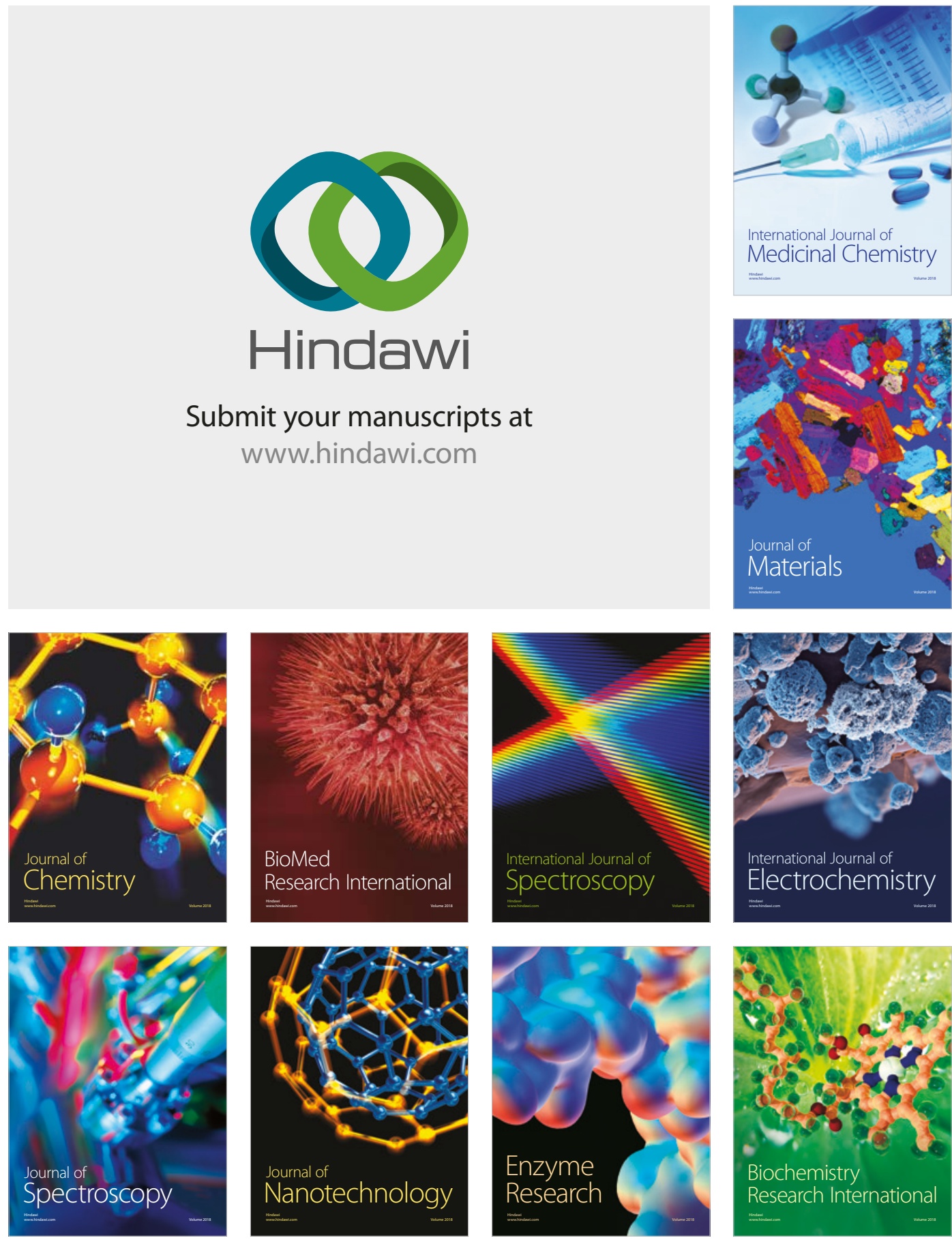
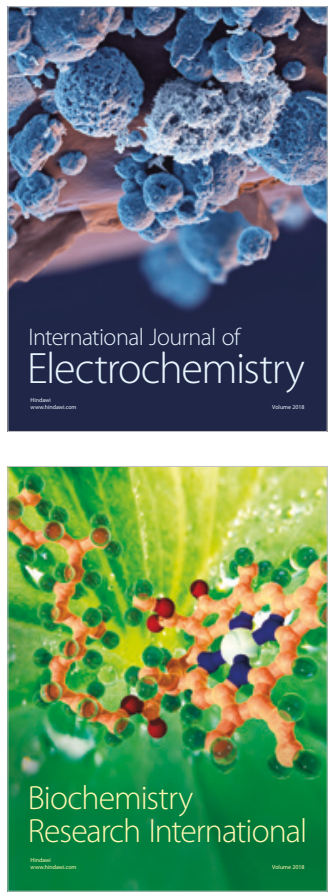